\title{
EMPLOYEE PERFORMANCE IMPROVEMENT MODEL BASED ON ISLAMIC WORK BEHAVIOR TO THE UMKM BATIK EMPLOYEES
}

Faizal Widya Kusuma*

\footnotetext{
* Affiliation:

Universitas Islam Sultan Agung Semarang email:

faizalwidyakusuma12@ gmail.com
}

\begin{abstract}
:
This study aims to describe and analyze the effect of education, training and work experience on Islamic work behavior and its impact on human resource performance. The population used is employees of batik UMKM in Central Java region. Based on the questionnaire distribution of 100 respondents, responded by the employees of 88 employees. The sampling technique is simple random sampling. The analysis tool is multiple linear regression, where previously tested the validity and reliability as well as the classical assumption test.

The result of the test shows that education on Islamic work behavior shows a positive influence, it can be interpreted that the higher level of education owned by employees, it will increasingly increase the change of attitude and employee's Islamic work behavior. Similarly, training and work experience also proved to have a positive effect on the behavior of Islamic work. Islamic behavior is proven to have a positive influence on the performance of human resources, can be interpreted that the higher the ability of employees in making changes in attitudes and behavior of Islamic behavior, it will further improve the performance of human resources.
\end{abstract}

keywords: Education, training, work experience, Islamic work behavior and human resource performance

\section{INTRODUCTION}

Human resource performance should increase over time. In performance, they just stop in place of certain businesses that run can roll the mat the passage of times and changes not familiar with the point of view first. For that is the necessary innovations that improve the performance of appropriate human resources. To improve the performance of human resources, required work behavior (Islamic).

Human resources implemented the behavior of Islamic work will feel a positive impact on him. When human resource apply Islamic work in daily behavior when the schedule of prayer had arrived immediately to the mosque to perform acts of worship to pray in congregation. 
This affects the behavior of Islamic work on human resources on the process of making human resources have trustful and loyal behavior. Due to the level of the 5-time prayers on time explained that the mandate of human resources and loyal to Allah when prayers schedule has arrived and hasten to pray in Congregation.

Islamic work behavior can also enhance cooperation in teamwork because the prayer in the congregation also symbolizes the cooperation that can be used as guidelines in both works. HR work good Islamic behavior, will feel the comfortable and peaceful time of worship and work because of legislation in accordance with the teachings of Islam. Verily, those who give priority to perform worship to God Almighty will be raised in degree and given sustenance, though visible waste time and may affect the performance, it's only a momentary effect, because Islamic work behavior can affect an individual's character became more disciplined and professional when encountering problems on the job can finish with the best way and not detrimental to the other party. In order to work with Islamic behavior can be improved, then many of the factors that influenced him, including the role of education, training and work experience.

Education is a process of getting knowledge that has always developed following the shift in time. In the process of education, HR acts as input to the process of education. HUMAN RESOURCES with the skills which have an impact on the behavior of labor, knowledge, attitude, action, appearance, and so on. Level of education human resources can improve the competitiveness of enterprises (UMKM) batik and improve the performance of the company Hariandja, (2002:169). It is inseparable from the more educated a person than the mindset that there are more advanced and developed. Very is inversely proportional to the circumstances of the MSME batik mostly human resources only the educated middle-down. Education on the MSME batik is not too important, because in working at MSME units required is just a special skill in the field of work who had so often underestimate education aspects.

Training within the Organization aimed at improving the mastery of a wide range of skills and techniques of implementing specific, detailed work and routine Handoko (2002:104). In training, he created an environment where employees can obtain or learn the attitudes, abilities, skills, knowledge, and behaviors that are specifically related to the job. Training usually focuses on providing employees special expertise. The intended change is the change in the behavior of positive human resources and is required to have a work behavior of Islamic concepts in developing any ideas thoughts that there is.

Experience is the knowledge that is known and controlled by a person due to a job at a specific time Trijoko (1980). Experience making human resource become formidable to undergo work. The more experienced, human resources more easily develop his thinking because of the wide variety of experiences that make human resource thoughts more and expected better than other human resources. The more human resources to handle the work of the various levels, making human resources growing better than the time before because he has experience.

The existence of humab resource on the MSMEbatik is stillat the top level. It is inseparable from the role of human resources in the areas of planning, monitoring, and maintenance is the most important and the most innovative ideas that make HUMAN RESOURCES have a vital role in production activities. With the capability of HUMAN RESOURCES can develop his 
thinking to survive the era of globalization that faces most of the production on the MSME batik using a machine that can streamline time and costs.

Development thought and innovation requires the existence of an education that is owned by the human resources. Education is a description of the knowledge of human resources, is expected to target at advanced stage owned Soekidja (1992). With the capitalization of human resources education, able to improve the quality of work using education owned through knowledge, skills, and abilities. Human resource competencies will form the attitudes, behaviors, and knowledge. Education has limited time and characters do not age, anyone in need of education.

Human resources education at MSME batik is still low. Human resources education obtained at MSME batik are generally only at the level of medium-over as well as educational skills. Although mastering skills, the less support it because the Small Medium Enterprises innovation needed in the production of batik and need modern technology, most Human resources don't understand how modern technological operations. These things affect the performance of Small Medium Enterprises in the achievement of the purpose of batik. If Human resources had adequate education, production using modern technology can solve the problem. In addition, the family system makes low Human resources education, because education is not Small Medium Enterprises in question to work on Small Medium Enterprises, but the skills needed. So education is impressed less so it needs that impact the education of Human resources on Small Medium Enterprises low batik.

The training obtained from the community as well as the Government is usually based on awareness to improve the performance of human resources so that earned new skills and can be applied to improve its performance. Training undertaken is usually on the basis of personal volition or landing of Small Medium Enterprises so that human resources can increase work performance and knowledge increase as required Small Medium Enterprises to innovate and reach the goal. Quality improvement and skills through training are expected to give a positive impact on the performance of human resources and can achieve the purpose of MSME batik.

An important role for the Government of Indonesia as well as the perpetrators of Small Medium Enterprises of batik production to increase the value by way of improving the quality of materials and models produced batik made interesting so that people interested to buy batik and there own pride when wearing the original batik clothes from Indonesia. However the MSME batik still have constraints in the areas of finance, in terms of capital, capital in Small Medium Enterprises still account for a small Small Medium Enterprises so that it is difficult to develop its business, as well as human capital less trained and educated to support any activities of Small Medium Enterprises so that hit the target.

Based on research on the performance of human resources, education, training, experience working with Islamic behavior. Then the formula issue this study is "how to improve the performance of human resources through Islamic work and behavior can influence the level of education, training, work experience. Then the research questions (question research) that arise is How the influence of Human Capital that includes education, training, and work experience can shape the behavior of Islamic as well as its impact on performance the performance of human resources. 


\section{LITERATURE REVIEW}

\section{Education}

According to Sutrisno, Edy (2011:65) education is the totality of human interaction to develop human potential. Hariandja (2002:169) level of education human resources can improve the competitiveness of enterprises (MSME) batik and improve the company's performance.

The concept of education in the research of Rachmawati Fadillah, et al (2004) time taken in completing the length of secondary education which is, good education background and vocational or educational backgrounds. The present reality that human resource on Small Medium Enterprises to know more batik vocational education because there the human resources have special skills including batik, sewing, weaving, as well as according to other abilities possessed by human resources.

Education in Major Indonesian Language Dictionary (200) is the process of changing the attitudes and behavior of a person or group of people in an attempt to mature the human resources through teaching and training. In the legislation of the Republic of Indonesia Number 1 article 20 the Year 2003 on national education, the definition is a conscious effort and planned to bring about an atmosphere of learning and the learning process is rather the participant learners in developing positive potential to have the power of religious spiritual, self-control, personalities, intelligence, kind morals, as well as the necessary skills to dive into the community (Sisdiknas, 2003).

Education is often defined as the human effort to build his personality in accordance with the values in society and culture. Furthermore, education is defined as a way of business by a person or group in order to become mature and reach the level of a better life in the sense of mental (Hasbullah, 2008).

According to Basrowi (2010) education has the task of preparing human resources for development. Development measures always have to hand in with the demands of the times. So the man who worked on the unit can reach its goal of Small Medium Enterprises so as to improve its performance through education earned as well as affect the behavior of Islamic work that makes the behavior more religious.

Human resources who work on Small Medium Enterprises should also be highly educated, do not rely solely on skill alone because education is a way to change the viewpoints and ways of thought so that thrive better than the previous state. According to Muliani (2009), times development always bring up new issues that have not been thought of before. Education is important for facing future challenges. High education will allow human resources to absorb the information and practice into everyday life.

Formal education forms the value of a person especially in accepting new things (Suhardjo, 2007). The value of the employee himself can feel the influence of education is received so that made it better in terms of personal behave in society. Education is a step that is specified based on the participant's advanced students, a goal that will be achieved and the will would be developed. Education to change attitudes and behaviors of healthy living the human resources of Small Medium Enterprises of batik. According to UU SISDIKNAS number 20 (2003), education level consists of the level of education and compliance departments. Secondary education stages are defined based on the level of development of the learners, 
the goal will be achieved, well-developed skills. Study results showed Suhardjo (2007) under education has an impact on the behavior of Islamic work. Therefore the first hypothesis put forward in this study is :

\section{H1: The education effect on the behavior of the Islamic workplace.}

\section{Training}

The training aims to improve the mastery of a wide range of skills and techniques for implementing specific, detailed work and routine (Handoko, 2002). Human resources work on the MSME batik expected who have followed or want to attend training in order to understand what training is needed by him so that all the existing problems at the company and yourself can be solved and there is a solution to change the issue into an appropriate solution.

Through the training, employees can apply the knowledge gained during the training through the application of science in everyday life so obtained can be beneficial to the maximum and make him become better because of the knowledge that gains as well as make the behavior for the better due to the applied science will become a habit and become the attitude and behavior. Human resources work on the MSME batik given training so that the potential which exists in him could be developed according to their needs and the needs of the company to improve its performance. According to Simamora (2006:342) training is the process of changing the behavior of human resources in a given direction to enhance organizational goals.

Based on Simamora (1999:345), training is a series of activities increase the skills, experience, and attitude of the person. Increased expertise in human resources must be exactly appropriate batik MSME competence is needed, do not get the training applies only when training alone, but can be sustained so that gives long-lasting effect. But for reaching it takes a long process as well as the maintenance cost much like maintaining an attitude or a form of training that should be applied to real life to know how big is a function of the procurement training has been given.

Expertise and experience could also own channeled thoroughly so that there is no question that Scotch between human resources and Small Medium Enterprises of batik. Study results Handoko (2002) showed that the training effect on the behavior of Islamic work. Therefore the second hypothesis put forward in this study is :

\section{H2: Training effect on the behavior of the Islamic workplace}

\section{Work Experince}

A person's work experience shows the kinds of work that has been done and someone gives a great opportunity for someone to do a better job. In addition to making work better, an experience that will change the behavior of the possessed on employees to be better because of the demands of companies that require employees to performance increase based on a specific time period The more widely a person's work experience, the more someone skilled in doing a job and getting perfect anyway thinking patterns and attitudes in the Act to achieve the objectives that have been set. 
Puspaningsih (2004). Time of devotion as well as his understanding to interpret the job well Ranupandojo (1984:71). Old or whether a human resource working in a field in the MSME batik is also influential to the performance. The longer human resources working in the batik MSME will be the better, as more experienced and when decision making to promote the company and its performance can provide a positive impact not harming each other.

Experience is a knowledge that is known and controlled by a person due to a job at a specific time Trijoko (1980:82). Puspaningsih study results (2004) shows that work experience have an effect on the behavior of Islamic work. Therefore the proposed third hypothesis in this study was:

\section{H3: Work experience has an effect on the behavior of Islamic work.}

\section{Islamic Working Behaviour}

According to Gibson et al (1996) defines behavior work as individual activity on an organization in achieving the objectives of the Organization presented a work behavior. Robbins (2002) describes the sense of behavior work as people in the work environment can actualize himself through attitude in work that emphasizes on the attitude taken by the worker to determine what will be done on the work environment.

Rizk in Marri, et.al (2012) defines the behavior of the Islamic work as an orientation towards the work and approach it as policy in human life. Extended our understanding puts the Islamic values of behavior, such as regulating all aspects of life). While according to Hayaati in Marri, et.al (2012) defines the behavior of the Islamic work as a reflection of the good values in action, even though the liver.

Ahmad (2012) defines the behavior of the Islamic work as a set value or belief system derived from the Qur'an and Sunnah/Hadith regarding action in work and hard work. Islamic work behavior can be interpreted as a benchmark for human resource activities that lead to goals that have been set, so that the work of Islamic behavior can affect the performance of human resources that made its performance increasingly quality so that it can actualize yourself through work attitude in accordance with the environmental organization based on the principles of the (Islamic) (Kusumawati, 2015).

Islamic work behavior indicators according to Muchlis (2012) quoted Kusumawati (2015) obtained from the values of the Qur'an has a work commitment, namely honest, earnest in his work, mandate and sincere

Indikator perilaku kerja islami menurut Jumaidi Subur antara lain sanggup bekerja secara ikhlas, sanggup bekerja dengan mawas, sanggup bekerja secara cerdas, sanggup bekerja dengan kerja keras dan sanggup bekerja secara tuntas.

Spiritual or behavior that is in accordance with the rules of Islam is an absolute requisite religion which can be controlled or run by every individual when running a job. Spiritual level one's good performance can improve the quality of Human Resources on the work, emotional tension, as well as a sense of not quite against the exertion, results already received. Sometimes this brings up a negative attitude in terms of Human Resources. These points make the spiritual as one dimension that can change and shape the attitudes and behaviors of human resources, form a quiet behavior and make the work as a valuable and meaningful (Rahman \& prosperous, 
2015). Study results Muchlis (2015) indicates that the behavior of Islamic work has an impact on the performance of human resources. The fourth hypothesis is therefore proposed in this study is:

\section{H4: Working behavior of Islamic influence on the performance of human resources.}

\section{Human Resources Performance}

HR performance is the translation of the performance which means the work of a worker, a management process or an organization overall, the result must be expressed in concrete proof and can be measured ( compared to a standard that has been their (Sedarmayanti, 2011). The performance of human resources an important part in the progress of the world's workforce, as well as the development of the company for the better in the performance of human resources existing in the company, has great capabilities and fighting spirit to achieve the targets that they set. Therefore this makes the author interested in researching further matters related to the performance of human resources.

According to Anwar, Mangkunegara (2009:67), the performance of Human Resources is the result of work in quantity is achieved by an officer in carrying out his duties in accordance with the responsibilities given to him. The results of the work done in a sustainable way even though you're not invited here, working assessment at MSME wear batik Executive because according to the tagline of new student programs. Therefore, in other words, human resources should be able to develop all the potential which exists in him for reaching the goal of success for him as well as to Small Medium Enterprises of batik in particular. According to Wibowo (2010:7) suggested that the HR performance is about doing the work and the results achieved from the work.

\section{RESEARCH METHODOLOGY}

Population set out in this research are human resources in Small Medium Enterprises of batik in Central Java that add up to 100 people. See the number of the population of 100 people, only then it deserves to be taken all to serve as samples so that this research is a research census.

To obtain the data, researchers deploy questionnaires as much as 100 units to employees scattered Batik MSEME in Central Java, as described here:

Table 1

Sample and Returns Level

\begin{tabular}{llcc}
\hline No & \multicolumn{1}{c}{ City } & Disemination & Return \\
\hline 1 & Solo & 30 & 27 \\
2 & Pekalongan & 30 & 28 \\
3 & Semarang & 20 & 18 \\
4 & Kudus & 20 & 15 \\
& Total & 100 & 88 \\
\hline
\end{tabular}

Methods of data analysis done with test quantitative analysis with linear regression analysis tool is a double which previously done test validity and reliability test requirements 
and assumptions. As for the regression equation can be written as follows:

$Y_{1}=a+b_{1} X_{1}+b_{2} X_{2}+b_{3} X_{3}$

$\mathrm{Y}_{2}=\mathrm{a}+\mathrm{b}_{1} \mathrm{Y}_{1}$

\section{Notes :}

$\mathrm{Y} 1=$ Islamic Working Behaviour

Y2 = Human Resource Performance

$\mathrm{X} 1$ = Education

$\mathrm{X} 2=$ Trainings

$\mathrm{X} 3=$ Wok Experience

$\mathrm{a}=$ Constants

\section{result and dIscussIon}

\section{Test validity and Reliability}

Results of testing the validity of each variable on the education, training, work experience, working with Islamic behavior against human resources performance results obtained pointed out. This is evidenced by all grades $r$ count on the indicator variables obtained exceeds the $\mathrm{r}$ value table of 0.2461 so thus each indicator on each of these variables can be made to the measures next calculation.

Reliability test results showed that all the value of Cronbach Alpha is greater than the specified limit of 0.7 . Thus, the reliability test results to the overall variables are reliable.

\section{Classic Assumption Test}

A classic assumption test is a test to find out requirements or no deviation data regression tested before.

\section{Multicollinearity}

\section{Table 2}

Multicollinearity Test

\begin{tabular}{lccc}
\hline \multirow{2}{*}{ Research Variable } & \multicolumn{2}{c}{ Collinearity Statistics } & Notes \\
& Tolerance & VIF & \\
\hline Education & 0,559 & 1,790 & There is no multicollinearity problem \\
\hline Trainings & 0,377 & 2,650 & There is no multicollinearity problem \\
\hline Work Experience & 0,339 & 2,950 & There is no multicollinearity problem \\
\hline Islamic Working Behaviour & 0,277 & 3,608 & There is no multicollinearity problem \\
\hline
\end{tabular}

\section{Heteroscedasticity}

Table 3

uji heteroscedasticity

\begin{tabular}{lccl}
\hline \multicolumn{1}{c}{ Research Variable } & Sign & $\begin{array}{c}\text { Significant } \\
\text { Limit }\end{array}$ & \multicolumn{1}{c}{ Notes } \\
\hline Education & 0,827 & 0,05 & There is no heteroscedasticity \\
\hline Trainings & 0,906 & 0,05 & There is no heteroscedasticity \\
\hline Work Experience & 0,133 & 0,05 & There is no heteroscedasticity \\
Islamic Working Behaviour & 0,504 & 0,05 & There is no heteroscedasticity \\
\hline
\end{tabular}




\section{3. normality}

To find out which can be shown by Gaussian normality graph shown with P-graph plots and normality of the data with the value Kolmogorof Smirnof. Following the results of the process of normality testing its calculations were aided by the program SPSS:

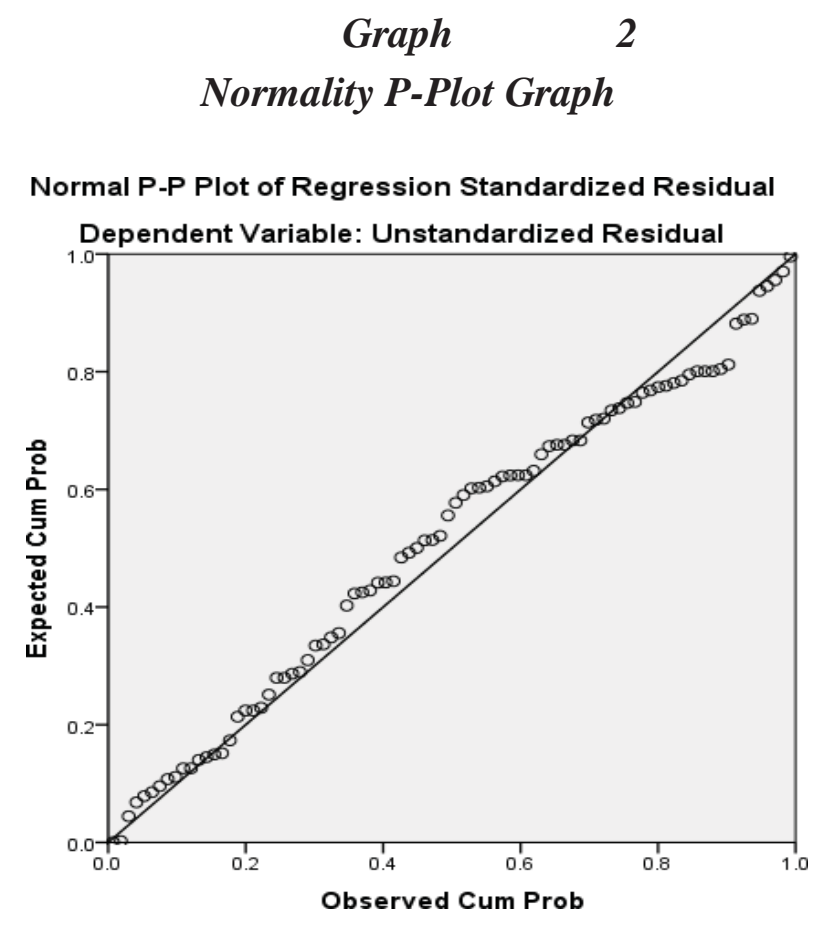

Based on the image shows that the data to follow and approach along the lines of diagonal, meaning that the data distribution is said not to follow and approach the line along the diagonal lines so that it can be concluded that the results of testing normality on a normal Gaussian variables.

\section{Table 4}

Normality Data

\begin{tabular}{c|ccl}
\hline Sample & $\begin{array}{c}\text { kolmogorof } \\
\text { Smirnof Z Value } \\
\text { (unstandrized Residual) }\end{array}$ & Sign & \multicolumn{1}{c}{ Noters } \\
\hline 88 & 0,087 & 0,099 & $\begin{array}{l}\text { Normally } \\
\text { Distributed }\end{array}$ \\
\hline
\end{tabular}

Based on the results of testing the normality of the data that in the sample of 88 respondents, show that for testing variable variables education, training and work experience as well as the work of Islamic behavior against human resource performance Gaussian, as evidenced by the value of their significance in testing that have exceeded the level error of 0.05 $>0.099$. 


\section{MULTIPLE Linear Regression}

Table 5

Regression Equation Result

\begin{tabular}{lccccc}
\hline $\begin{array}{c}\text { Research } \\
\text { Variabke }\end{array}$ & $\begin{array}{c}\text { Regression } \\
\text { Coeffisient }\end{array}$ & $\begin{array}{c}\text { t } \\
\text { hitung }\end{array}$ & Sig & Notes \\
\hline$X_{1} \rightarrow Y_{1}$ & 0,160 & 2,138 & 0,035 & Ha accepted \\
$X_{2} \rightarrow Y_{1}$ & 0,377 & 4,493 & 0,000 & Ha accepted \\
$X_{3} \rightarrow Y_{1}$ & 0,422 & 4,835 & 0,000 & Ha accepted \\
\hline$Y_{1} \rightarrow Y_{2}$ & 0,890 & 18,058 & 0,000 & Ha accepted
\end{tabular}

The results of the regression equation as described above is expressed with the Component Coefficients with the consideration that the variable size approximate (Ghozali, 2013) so that the equation the regression can be described as follows:

$\mathrm{Y}_{1}=0,160 \mathrm{X}_{1}+0,377 \mathrm{X}_{2}+0,422 \mathrm{X}_{3}$ $\mathrm{Y}_{2}=0,890 \mathrm{Y}_{1}$

The results of the regression equations above can be interpreted as follows:

1. The value of the regression coefficient for the variable behavior work against Islamic education has a positive value of 0.160 and significance of 0.035 , giving the sense that the higher the educational level of the employee, it will increasingly improve the working attitude and behavior change in Glbt employees, assuming the other variables are constant.

2. The value of the regression coefficient for the variable behavior work against Islamic training is positive of 0.377 and significance of 0.000 , giving the sense that the higher the training is given to employees, it will increase a change in attitude and behavior work Glbt employees, assuming the other variables are constant.

3. The value of the regression coefficient for the variable work experience toward Islamic work behavior also shows positive values of 0.422 and significance of 0.000 , giving the sense that the more extensive work experience of the employees, then the employee will be the more skilled in doing the work, so that will further improve the working attitude and behavior change in Glbt employees, assuming the other variables are constant.

4. The value of the regression coefficient between Islamic work behavior on the performance of human resources has a positive value of 0.890 with the significance of 0.000 , giving the sense that the higher the change in attitude and behavior of the Islamic workplace employees, it will further improve the performance of human resources, assuming the other variables are constant.

\section{The Influence Of Education Against The Islamic Workplace Behavior}

The test results of education against the behavior of the Islamic work retrieved value $t$ calculate of 2.138 to the value significance of $0.035<0.05$. On the degree of freedom of 84 (n $-\mathrm{k}-1 ; 88-3-1)$, obtained a value of the $\mathrm{t}$ table of 1.9886 , so the value $\mathrm{t}$ calculate $=-\mathrm{t}$ table value $<2.069=-1.9886$. With those results give a sense that education has a negative influence on work behavior against Islami. Based on the test results it can be concluded that the test is able to receive the first hypothesis, so the existence of the alleged influence of education against the 
Islamic workplace behavior proved or accepted.

\section{The Influence Of Training Against Islamic Work Behavior}

The results of the test variables against Islamic work behavior training retrieved value $\mathrm{t}$ calculate that is of significance to the results amounted to $4.4930 .000<0.05$, so the value $t$ calculate $=4.493>$ value $t$ table of 1.9886 . This means that the training had a positive influence on Islamic work behavior. Based on the test results it can be concluded that the test is able to receive the second hypothesis, so the existence of the alleged influence of training Islamic work behavior against proven or accepted.

\section{Influence of work experience towards Islamic Work Behavior}

The test results between work experience against the behavior of the Islamic work retrieved value $t$ calculate of 4.835 with significance value of $0.000<0.05$. Thus the value $\mathrm{t}$ calculate 4.835 has exceeded the value of $\mathrm{t}=1.9886$ table meaning that work experience a positive effect against Islamic work behavior. Based on the test results it can be concluded that the test is able to receive the third hypothesis, so the existence of the alleged influence of work experience towards Islamic work proven behavior or acceptable.

\section{The influence of Islamic Work Behavior on the performance of Human Resources}

Islamic work behavior test results against the performance of human resources retrieved value $t$ calculate of significance value of $18.0580 .000<0.05$. On the degree of freedom of 86 $(\mathrm{n}-\mathrm{k}-1 ; 88-1-1)$, obtained a value of the $\mathrm{t}$ table of 1.9879 , will value $\mathrm{t}$ calculate of 18.058 $>1.9879$. With those results give a sense that Islamic work behavior has a positive influence on the performance of human resources. Based on the test results it can be concluded that the test is able to receive the fourth hypothesis, so the existence of the alleged influence of proven or accepted.

\section{The influence of Education against the Islamic workplace Behavior}

Results of the study proved positive effect that education against Islamic work behavior, may imply that the higher level of education of employees, such as concern for the level of education, compliance departments and the pattern of thought, then It will further improve the working attitude and behavior change in Glbt employees. This statement Suhardjo (2007) that formal education may establish the value of a person especially in accepting new things. This means that the value of the employee himself can feel the influence of the education is received so that made it better in terms of personal behave in society. The results of these study support findings made by Suhardjo (2007) showed that education has an impact on the behavior of the Islamic workplace.

\section{The Influence Of Training Against Islamic Work Behavior}

Based on the results of the study proved that the training had a positive influence on Islamic work behavior. In other words, may imply that the higher the training is given to 
employees, such as the existence of adequate training facilities, upgrade, training materials, good training and instructor excited and interested in following the training, it will improve the working attitude and behavior change in Glbt employees. This statement Simamora (2006) that the existence of training then it can change the behavior of the human resources in a given direction to enhance organizational goals. The results of this study support the research of John Greenwood (2002) showed that the training effect on the behavior of the Islamic workplace.

\section{Influence Of Work Experience Towards Islamic Work Behavior}

Work experience is proven to have a positive influence on Islamic work behavior, can be interpreted as that the more extensive work experience, work experience in many places, a varied life experiences, viewpoints and attitudes of professional and how diligent attitude and point of view, then the employee will be more skilled in doing the work, so that will further improve the change in attitude and behavior of Islamic work. According to Ranupandojo (2009) explains that the more extensive work experience of someone, the more someone skilled in doing a job and getting perfect anyway thinking patterns and attitudes in the Act to achieve the objectives that have been set. This study supports the results of the findings made by Puspaningsih (2004) shows that the work experience have an effect on the behavior of the Islamic workplace.

\section{The influence of Islamic Work Behavior against human resource Performance}

The behavior of the Islamic work proved to have a positive influence on the performance of human resources, may imply that the higher the employee's ability to make changes in the change in attitude and behaviour of Islamic work, such as the attitude to work hard, work thoroughly, sincere when working and earnest in work, it will further improve the performance of human resources. Islamic work behavior can affect the performance of human resources made increasingly qualified performance so that it can actualize yourself through work attitude in accordance with the environmental organization based on Islamic principles ( Kusumawati, 2015). This research supports findings Muchlis (2015) indicates that the behavior of Islamic work has an impact on the performance of human resources.

\section{CONCLUSION}

Education against Islamic work behavior shows a positive influence, may imply that the higher level of education employee-owned, then it will certainly further improve work attitudes and behaviors change Glbt employees. The training effect is positive toward Islamic work behavior, meaning that the higher the training given to employees, it will improve the working attitude and behavior change in Glbt employees. Work experience is proven to have a positive influence toward Islamic work behavior, can be interpreted as that the vast experience of work of employees, then the employee will be more skilled in doing the work, so that will further improve the changes attitude and behavior of Islamic work. The behavior of the Islamic work proved to have a positive influence on the performance of human resources, may imply that the higher the employee's ability to make changes in the change in attitude and behavior of Islamic work, it will further improve the performance of human resources. 


\section{REFERENCES}

Andrawina, Luciana, dkk 2008. Hubungan antara knowledge sharing capability, absorptive capacity dan mekanisme formal: Studi kasus industri teknologi informasi dan komunikasi di Indonesia. Jurnal teknik industri Vol. 10 No. 2 Hal. 158-170

Abar, F.N. dan Noermijati. 2012. Pengaruh Motivasi Intrinsik dan Extrinsik terhadap Kinerja Karyawan Pada PT Perkebunan Nusantara XII Surabaya.

Duran, E, Duranch, Honey, J, \& Scheuerman, A. 2011. A Learning Cycle For All Student. Oshio : Sat Links.

Fitri, Hanna. 2013. Lanjut Usia Bekerja (Studi Kasus di Keluraha Simpang Baru Kecamatan Tampan Kota Pekanbaru). Skripsi Jurusan Sosiologi Fakultas Ilmu Sosial dan Ilmu Politik Universitas Riau.

Ghozali, Imam. 2011. Aplikasi Analisis Multivariate. Semarang : Badan Penerbit Universitas Diponegoro.

Hameed, Abdul dan Aamer Waheed. 2011. Employed Development and Is Affectan Employed Peformance A Conseptual Framework, International Journal of Busisness and Social Science. Vol 2 No 13.

Hsing-Kuo Wang, Yu-Fang Yena, Cheng-Fei Tsai, Yu-Chieh Lin, 2008, “An Empirical Research on The Relationship Between Human Capital and Innovative Capability: A Study On Taiwan's Commercial Banks", Total Quality Management, Vol. 19, No. 11, P.1189-1205

Isyanto, Puji, Sungkono, Cyntia Desriani. 2013. Pengaruh Pengembangan Karier Karyawan Terhadap Motivasi Kerja Karyawan Pada PT Excal Utama Indonesia Karawang, Journal Manajement. Vol 10 No 3.

Juwita Anggraini. Desember 2007. Jurnal Akuntansi dan Keuangan Indonesia. Pengaruh Human Capital Terhadap Business Performance, Vol.4, No. 2, hal. 229-250

Miftahun Huda.2013.Model-Model Pengajaran dan Pembelajaran. Yogyakarta : Pustaka Pelajar.

Ryan, R. M. , Dea, E. L. 2010. Intrinsic and Extrinsic Motivations Classic Definitions and New Directions. Educational Psychology.54-67.

Sekaran, 2009. Research Methods For Busisness Methodology Penelitian Untuk Bisnis. Jakarta: Salemba Empat.

Simamora, H. 2012. Manajemen Sumber Daya Manusia. Cetakan Pertama. Yogyakarta : STIE- YPKN.

Sugiyono, 2010. Metode Penelitian Bisnis, Cetakan Keenam. Bandung : CV Alpha Betha.

Venkatesh. V., Dennis, A, R., \& Brown, S. A. 2010. Prodecting Collaboration Technology Use: Integrating Technology Adoption and Collaboration Research. Journal of Management Information System, 27(2):9-54.

Wibowo. 2011. Manajemen Kinerja. Rajawali : Pers Jakarta.

Wibowo. 2009. Manajemen Kinerja. Jakarta Pusat : PT Raja Grapindo. 
Widodo. 2008. Model Pengembangan Evaluasi Strategi. Majalah Ekonomi, Tahun XIX, No.1 (April 2009) 